\title{
Use and application of information and communication technologies in the students of the degree in administration of the Tecnologico de Calkini
}

\section{Uso y aplicación de las tecnologías de la información y comunicación en los estudiantes de la licenciatura en administración del Tecnológico de Calkiní}

\author{
BACAB-SANCHEZ, José R.*๋, AVILA-ORTEGA, Jorge I., SANTOS-VALENCIA, Raúl A. and \\ MAY-OSIO, Eduardo
}

Instituto Tecnológico Superior de Calkiní en el Estado de Campeche, Av. Ah Canul, por Carretera federal, S/N, Código postal 24900

ID $1^{\text {st }}$ Author: José R, Bacab-Sanchez / ORC ID: 0000-0002-8861-0852

ID $1^{\text {st }}$ Coauthor: Jorge I., Avila-Ortega / ORC ID: 0000-0001-5267-2261

ID $2^{\text {nd }}$ Coauthor: Raúl A., Santos-Valencia / ORC ID: 0000-0002-9824-8789

ID $3^{\text {st }}$ Coauthor: Eduardo, May-Osio / ORC ID: 0000-0003-0782-3002

DOI: $10.35429 / J C S I .2019 .15 .5 .25 .34$

Received March 27, 2019; Accepted June 05, 2019

\begin{abstract}
Currently, ICTs are necessary for growth and educational and social development. However, the simple provision of infrastructure and technological equipment to schools is insufficient, These require its proper articulation in the teaching-learning processes and proper school management. for this reason it is imperative to evaluate the use of ICT in young students of higher level in the Maya area of the Camino Real of the State of Campeche. The study is descriptive, with a quantitative approach, the design is non-experimental transactional, the method was the field study and the technique is the survey with the questionnaire as an instrument. The results indicate that one of the most deeply rooted devices among students is the cell phone; the Laptop is the machine that most students use to do their jobs and tasks; for this reason, this device represents an opportunity to work more with them, this device represents an opportunity to work more with them, this is favored by the public policies that have taken place in the area and have allowed students to access the internet in schools. Therefore, an ICT policy in the institution favors young students to increase their potential in the use of these technologies.
\end{abstract}

Students, Administration, Information Technology and communication

\begin{abstract}
Resumen
En la actualidad, las TIC son necesarias para el crecimiento y desarrollo educativo y social. No obstante, es insuficiente la simple dotación de infraestructura y de equipos tecnológicos a las escuelas, pues estas requieren de su correcta articulación en los procesos de enseñanzaaprendizaje y de una gestión escolar adecuada. Por tal motivo es imperante evaluar el uso de las TIC en jóvenes estudiantes de nivel superior en la zona maya del camino real del Estado de Campeche. El estudio es de tipo descriptivo, con enfoque cuantitativo, el diseño es no experimental transaccional, el método fue el estudio de campo y la técnica es la encuesta, con el cuestionario como instrumento. Los resultados indican que uno de los dispositivos más arraigado entre los estudiantes es el teléfono celular; la Laptop es la máquina que más emplean los alumnos para hacer sus trabajos y tareas; por tal motivo, este dispositivo representa una oportunidad para trabajar más con ellos, esto es favorecido con las políticas públicas que se han dado en la zona y han permitido que los alumnos acceden a internet en las escuelas. Por lo que una política de TIC en la institución favorece que los jóvenes alumnos incrementen su potencial en el uso de estas tecnologías.
\end{abstract}

Estudiantes, Administración, Tecnologías de la Información y comunicación

Citation: BACAB-SANCHEZ, José R., AVILA-ORTEGA, Jorge I., SANTOS-VALENCIA, Raúl A. and MAY-OSIO, Eduardo. Use and application of information and communication technologies in the students of the degree in administration of the Tecnologico de Calkini. Journal of Computational Systems and ICTs. 2019, 5-15: 25-34.

\footnotetext{
* Correspondence to Author (email: jrbacab@itescam.edu.mx)

$\dagger$ Researcher contributing first author.
} 


\section{Introduction}

Today, each young person is required to have access to a relevant and modern preparation and learning. Even more so in the current times where information is available in different forms and formats, which represents a demand, that although it is true equal or greater in the effort than 30 years ago, it is currently renewed and influenced by a situation where Information and Communication Technologies (ICT) are already in greater availability than in the past. In these times, ICTs are already necessary for educational and social growth and development.

Coll (2008) mentions that the increasing centrality of education and training in the information society has been accompanied by an equally growing role of ICT in educational and training processes.

Technology has advanced and continues to progress, and progress is also made in the way it is used.

Today, the use is dynamic and complex. Because computers are connected to different networks and technology in general is more integrated into our lives. However, the connection between the use of ICTs and pedagogy is notorious., (Aris y arcos, 2015).

The ability of ICTs to promote social inclusion, limit geographic dependence between teacher and student, and enable access to a large amount of information, has been especially valued for the construction of more interactive teaching environments and educational experiences more dynamic learning.

However, achieving the adequate incorporation of these resources into education requires a great effort. The simple provision of infrastructure and technological equipment to schools is insufficient. The effective incorporation of ICT in the academic practices of students and teachers, inside and outside the classroom, requires its correct articulation in the teaching-learning processes and an adequate school management that modifies the organizational structure and promotes its use, (Hernández, L.; Acevedo A., Martínez C., Cruz, C., 2014)
Therefore, one of the fundamental roles of education in educational institutions and the actors involved in them is to make ICTs properly used by students in their professional training, making them more competent for society.

\section{Problem Statement}

In the 21 st century, higher-level schools face a dynamic and versatile society, with an increasing speed in data transfer and dominated by information and communication technologies (ICT). In this sense, educational centers must be organizations that adapt, update and assume changes in the knowledge society, especially in the integration of ICTs in their educational practices, (Sosa and Valverde, 2015). In this new social and cultural plot, students must acquire competences in Information and Communication Technologies for their academic challenge and their subsequent professional occupation.. It is complex the introduction of information and communication technologies in schools and much more the adoption that students make correctly and appropriately in their use of all these available devices and the technology itself.

In the preparation and training of young people, one must be sensitive about these new current challenges and provide alternatives in terms of learning modalities. It should be borne in mind that replacing old media with new technologies without another change in teaching systems does not help much. For all this, the research question arises. How are students of the degree in administration of the Tecnológico de Calkiní using ICT in their activities?

\section{Objective}

Evaluate the use of ICT in young students of higher level in the Mayan area of the royal road of the State of Campeche.

\section{ICT skills from the pedagogical dimension}

The competences related to the implementation in educational scenarios of learning experiences supported by ICTs account for the skills that allow the design and planning of an educational scenario to be launched, and which are reflected in the educational practices of a teacher. 
Finally, the competencies of evaluation of the effectiveness of the educational scenarios supported by ICTs are related to the Skills that allow the teacher to assess the effectiveness to favor significant learning in students by incorporating ICTs into their educational practices, (Pontificia Universidad Javeriana de Cali y UNESCO, 2016).

It is important to note that the levels of appropriation in relation to the proposed competences are evaluated based on the activities designed by the teachers. In that order of ideas, a single level of competence cannot be attributed to each teacher. The levels are set based on how they use technology in specific practices, (Pontificia Universidad Javeriana de Cali y UNESCO, 2016).

\section{Framework of Competences of Teachers regarding ICT}

To effectively integrate ICT in teaching and learning, a redefinition of the role of teachers in the planning and application of these technologies is required, in order to change and improve learning. Education systems should regularly update and improve the preparation and professional training of teachers and ensure that all teachers can take advantage of technology for educational purposes, (UNESCO, 2019).

The UNESCO Framework of Competences of ICT Teachers seeks to help countries to develop comprehensive national regulations on ICT competencies for teachers and incorporate them into the general plans for the use of ICT in education, (UNESCO, 2019).

Digital competencies are defined as a spectrum of competencies that facilitate the use of digital devices, communication applications and networks to access information and carry out better management of these.

These competences allow to create and exchange digital content, communicate and collaborate, as well as to solve problems with a view to achieving effective and creative development in life, work and social activities in general, (Unesco, 2018).
In general, the basic digital competences, that is, the fundamental functional competences for the elementary use of digital devices and online applications, as well as the conventional skills of reading, writing and calculation, are considered to be part of essential to the new range of literacy skills during the digital era, (Unesco, 2018).

To make people progress in a connected economy and society, digital skills must also go hand in hand with solid literacy and calculation skills, critical and innovative thinking, solutions to complex problems, the ability to collaborate and socio-emotional capabilities, (Unesco, 2018).

\section{The use of ICT}

ICTs should be used appropriately, with a sense that allows the development of fairer, more democratic and inclusive societies, so as to strengthen collaboration, creativity and the more equal distribution of scientific knowledge and contribute to a more equitable and quality education for all (Unesco, 2013).

The use of ICTs can contribute to the development of a number of transversal skills, such as social competence, communication and organization skills, time management and available technological resources. ICT represents a tool to facilitate the development of collaborative approaches to learning and stimulates autonomous student-centered learning. On the other hand, it contributes to generating higher education opportunities and benefits students from having development opportunities, (Sangrá A. y González M., 2004)

The use of ICTs, in the educational environment, has had processes of revealing changes, its impact has been recognized in relation to reforms, it is known that the impact of any technology depends on how it is used, in what context and for what purposes, since it opens up possibilities as well as new demands (Bebell, 2005). In the educational system the uses of new technological systems are slow, however, education should be a decisive instrument of the policy to reduce the digital divide. However, the penetration of ICTs in schools and classrooms is still limited and their incorporation is facing more difficulties than expected. The possibility of access will become another factor of inequality in which many young people are (Díaz, 2014).

BACAB-SANCHEZ, José R., AVILA-ORTEGA, Jorge I., SANTOSVALENCIA, Raúl A. and MAY-OSIO, Eduardo. Use and application of information and communication technologies in the students of the degree in administration of the Tecnologico de Calkini. Journal of Computational Svstems and ICTs. 2019. 


\section{The ICT classification}

On the other hand Perreault (2005), Classifies ICTs by dividing it into three categories, in the first one are information technologies, which include the hardware and peripheral components of computers, software and computer knowledge; the second category is telecommunications technologies, where fixed telephone systems, radio and television transmissions are; and in the third category are network technologies, made up of the Internet, mobile phones and connectivity media.

Another classification is made by Gálvez (2015), in which it is observed that he classifies them into three categories:

a)

The networks in which the fixed and mobile telephony, the Internet, television and home networks are located, which are used for the transmission and reception of data.

b) The terminals, which are the physical parts that act as an access point and allow the reproduction of different formats of video music or games.

c) And ends with the services, which can be accessed from our Internet connections and can make transactions and share information with other people.

In general, information and communication technologies (ICT) are producing important transformations in society, to the point of marking the distinctive characteristics of this historical moment in relation to the past. At present there is an immediate possibility of accessing information generating a process of transformation in societies (Fernández and Delavaut, 2006).

In this tenure Vaquero (1999) cited by (Fernández and Delavaut, 2006), states that the education system has a vast possibility with ICT considering two aspects:

Knowledge, you cannot understand today's world without a minimum of computer culture. This understanding occurs through various ways in which this knowledge is transmitted.
Its use: ICT should be used to learn and to teach. That is to say, the learning of the subjects can be facilitated by means of the TIC and in particular by means of Internet applying the suitable techniques.

\section{ICT conceptualization}

The OECD (2002) defines ICTs as those devices that capture, transmit and display electronic data and information and that support the growth and economic development of the manufacturing and services industry.

Technology can also be defined as the set of knowledge of an industrial art, which allows the creation of artifacts or processes to produce them. Each technology has its own, exclusive and technical language, so that the elements that compose it are perfectly defined, (Cegarra, 2012).

Haag, Cummings and McCubbrey (2004), consider that information technologies are composed of any computer-based tool and that people use to work with information, support information and process information needs.

\section{Materials and method}

With this research project we have sought to analyze the use and evaluate the potential, as well as the application of ICT in higher education institutions in the Mayan area of the Camino Real in the State of Campeche and know its scope and impact on teaching, specifically in the Technological of Calkiní. Among the variables that were considered through this study were socio-demographic features, such as age and place of origin; educational and institutional linked to the education of respondents at the level of use of ICT resources; and assessments around the use of ICT in the teaching-learning processes of education centers in the northern region of the state of Campeche.

\section{Type and design of the study}

This study is descriptive, with a quantitative and mixed approach. Behar (2008) mentions that descriptive studies serve to analyze how it is and how a phenomenon manifests and its components. 
They allow to detail the phenomenon studied basically through the measurement of one or more of its attributes. For example, Social Science research deals with the description of the characteristics that identify the different elements and components and their interrelation.

The design is non-experimental transactional, since the participants belong to a certain group or level (all of them are educational centers), data are investigated in a single moment and in a single time, with the aim of describing variables and analyzing their incidence or interrelation at a given time (Hernández, Fernández and Baptista, 2010). The method is the field study and the technique is the survey, with the questionnaire as an instrument.

\section{Instrument}

For this research, a questionnaire was designed that served as an instrument taking into account the standards of ICT skills for teachers of the United Nations Educational, Scientific and Cultural Organization (UNESCO), (2008) and adapted by the Javeriana University of CaliUNESCO in 2016. In which it is considered first to have the basic notions, deepen the knowledge of ICT and then from which knowledge can be generated.

In part 1 . The personal data information of the students is contemplated as name, age, career and general activities related to ICT. This includes 11 open questions related to the time of use of the devices, internet access and hours dedicated to each activity.

In part 2. It is considered the related to the technological competences of the student, it includes 10 questions on the Lickert type scale to determine the knowledge, use, and application of ICT.

In part 3. It is considered the related to the learning competences of the students, here are considered 13 questions in scale type Lickert to determine the knowledge, employment, the application of the TIC'S in the tasks and school activities.
In part 4. It is considered what is related to the communication skills of the students, here 8 questions are considered at the Lickert type scale to determine the knowledge, use, application of ICT'S in terms of student communication.

In part 5. It is considered the related to the ethical behavior competencies of the students, here are considered 4 questions in scale type Lickert to determine the knowledge, use, application of ICT in terms of behavior.

A questionnaire was designed as discussed in the section of the instrument, shared with three experts to obtain a trial and make adjustments, in order to obtain a validity of it, (Hernández et al., 2010). The reliability of the instrument was obtained by applying a previous sample and subsequently obtaining the Cronbach's alpha which was greater than 0.90 .

\section{Participants}

In this phase of the study the students of the degree in administration of the different semesters of the Higher Technological Institute of Calkiní in the State of Campeche were selected. A total of 88 students participated, of which 45 were women and 43 were men. In more disaggregated form (see Table 1), the participation of the third semesters was held with a total of 64 students, of which 30 students were surveyed. The students of the fifth semester with a total of 56 students were also surveyed and of which 41 students were surveyed and finally the seventh semester was taken into account, which has a total of 42 students and in which 17 were surveyed students.

These semesters were taken since it was considered that the students have adapted to the Technology with a time greater than one year in the Institution.

\begin{tabular}{|l|c|c|}
\hline \multicolumn{1}{|c|}{ Semester } & $\begin{array}{c}\text { Enrolled } \\
\text { Students }\end{array}$ & $\begin{array}{c}\text { Sampled } \\
\text { Students }\end{array}$ \\
\hline Third & 64 & 30 \\
\hline Fifth & 56 & 41 \\
\hline Seventh & 42 & 17 \\
\hline Total & 162 & 88 \\
\hline
\end{tabular}

Table 1 Total students surveyed

Source: Made with field information, 2018 


\section{Process}

A questionnaire was designed as discussed in the section of the instrument, shared with three experts related to work in the academic area to obtain a trial and make adjustments, in order to obtain a validity of it, (Hernández et al., 2010).

In the phase of application of the instrument, the different teachers who teach in the degree of administration of the technology of Calkiní were asked to allow us to make a survey of the students who were at that time to determine how they are using and applying ICT in their homework and daily activities.

\section{Results}

Some of the results obtained.

Of the total of the students surveyed, $38.6 \%$ responded that they have the cell phone as a communication device for their personal use, this is equivalent to a total of 34 students. Laptop and cell phone follow and then only laptop (see graphic 1). That is, the laptop represents the tool' par excellence that the student community uses in their daily activities.

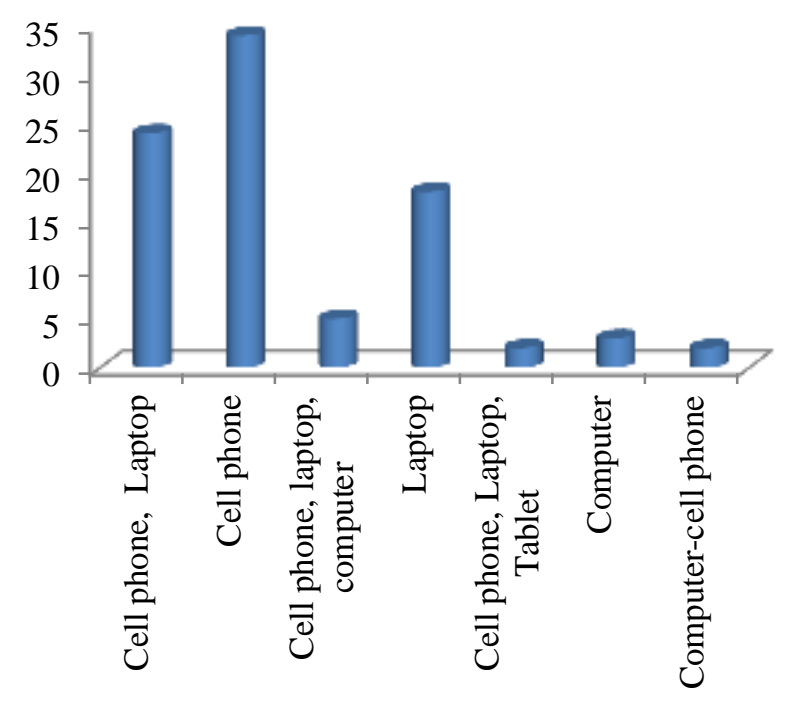

Graphic 1 Device that students have for personal use Source: Made with field information, 2018

It can be trivial but it is not when it comes to education because in rural areas of the State of Campeche there are still young people who do not have this tool (laptop), this shows that a public policy channel can be out there, continue encouraging it if it already exists and / or create it if there is not yet of this type.
On the other hand, $73.9 \%$ of students use the laptop to do their homework, followed by the use of the computer with $13.6 \%$ of the total respondents (see graph 2). Due to its versatility and ease of transfer, the laptop is the device most used by students.

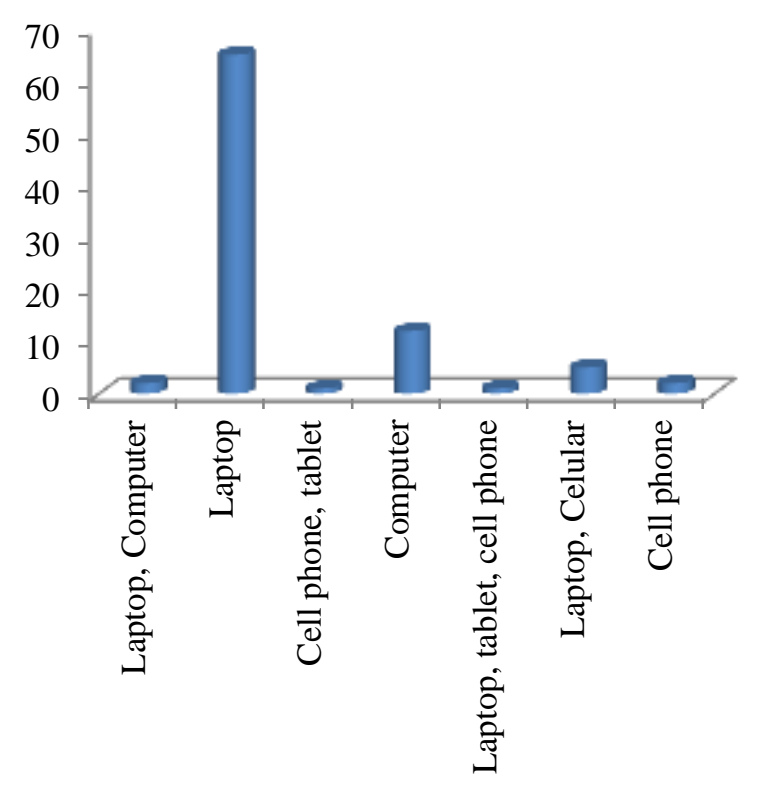

Graphic 2 Devices used by students to do their homework

Source: Made with field information, 2018

To the question, do you usually access the Internet since ?, $60.2 \%$ of the students answered that they do it from school, $19.3 \%$ do it from home, $5.7 \%$ use the cybercafé to enter the internet (see graphic 3). Another great finding because it can be seen that school is the main route by which young people access the internet.

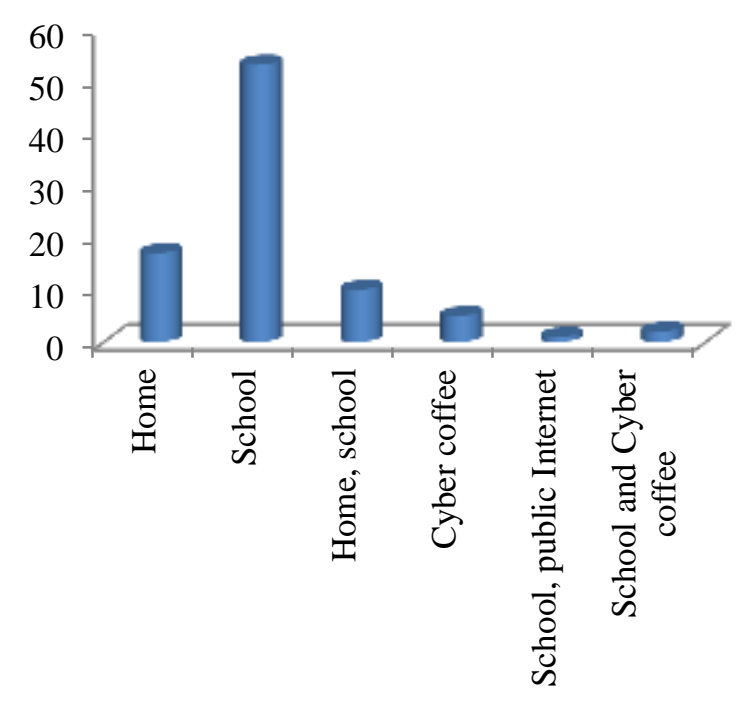

Graphic 3 Place from commonly access the internet Source: Made with field information.

BACAB-SANCHEZ, José R., AVILA-ORTEGA, Jorge I., SANTOSVALENCIA, Raúl A. and MAY-OSIO, Eduardo. Use and application of information and communication technologies in the students of the degree in administration of the Tecnologico de Calkini. Journal of Computational Svstems and ICTs. 2019. 
This is when they are asked if they have internet at home since $69.3 \%$ mention that they do not have that service at home.

The social network that students use the most is Facebook (91\%), that is, less than $10 \%$ use another network like Instagram or WhatsApp.

On the other hand, the time of use of any of the devices such as Laptop, cell phone, computer, etc., per day was 5.6 hours on average for all respondents. The time on the internet to do their activities was 4.1 hours on average. In this sense, the time taken to do their homework was 4.5 hours on average per day. The time in a social network was 2.6 hours. Here is what students do per day and we see how time is used both inside and outside the technology.

On the other hand, when analyzing the technological competences related to the students, the following is presented:

The use of ICT to communicate with family members and other students was among the highest on the scale (greater than 4) along with the efficient use of the tools and services offered by the internet; On the other hand, the use of virtual learning environments and the use of specialized software to learn a subject were the lowest in the scale (graph 4). That is, there is no digital culture in which you can interact with teachers and other students to create learning environments and obtain professional training if you have to be present in a classroom or place. It is still something strange.

This indicates that we are at the beginning of the management of ICT by students because although it is true that they are known by the vast majority, they use them as communication, wasting the great potential that all this implies.

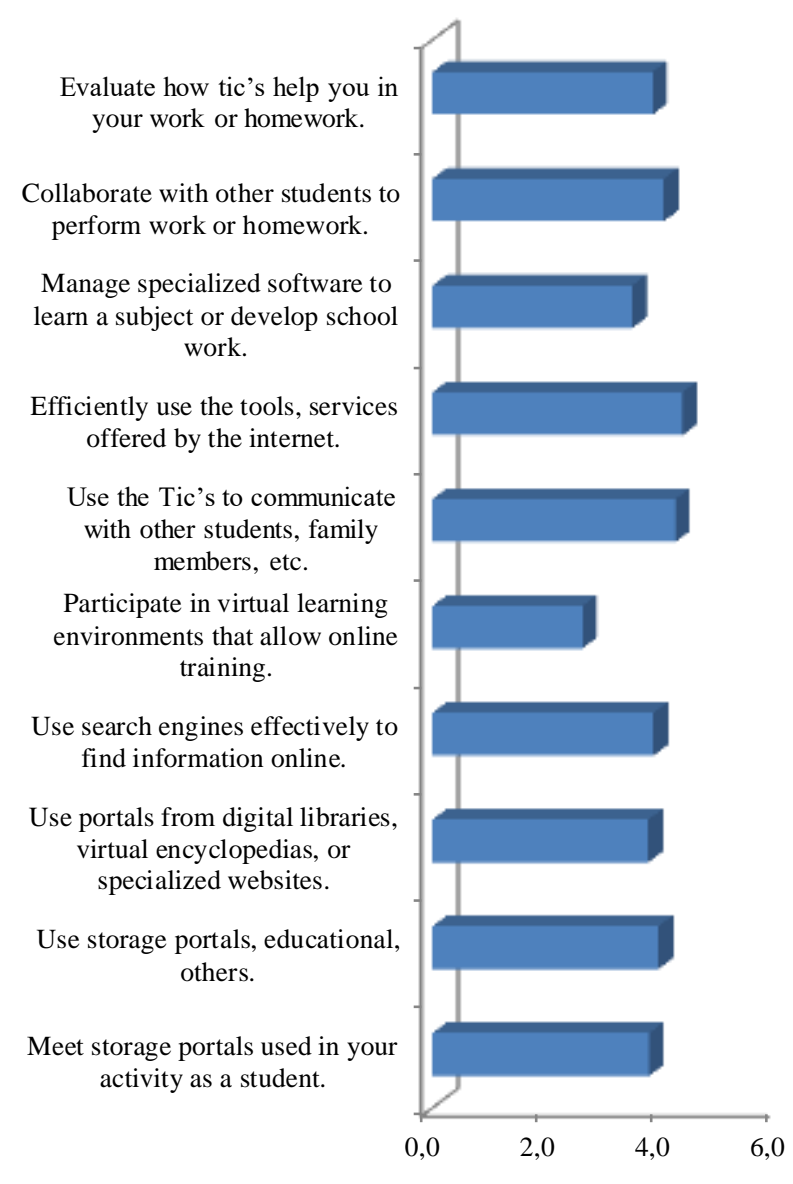

Graphic 4 Technological skills of the student Source: Made with field information, 2018

The students of the administration degree indicate that the search for information on the Internet to do their homework is what they do best, visits to the library are less frequent (graph 5). Participation in forums that contribute to improving the learning experience is less favored. Doubt or lack confidence in virtual environments having a lag in these aspects. 


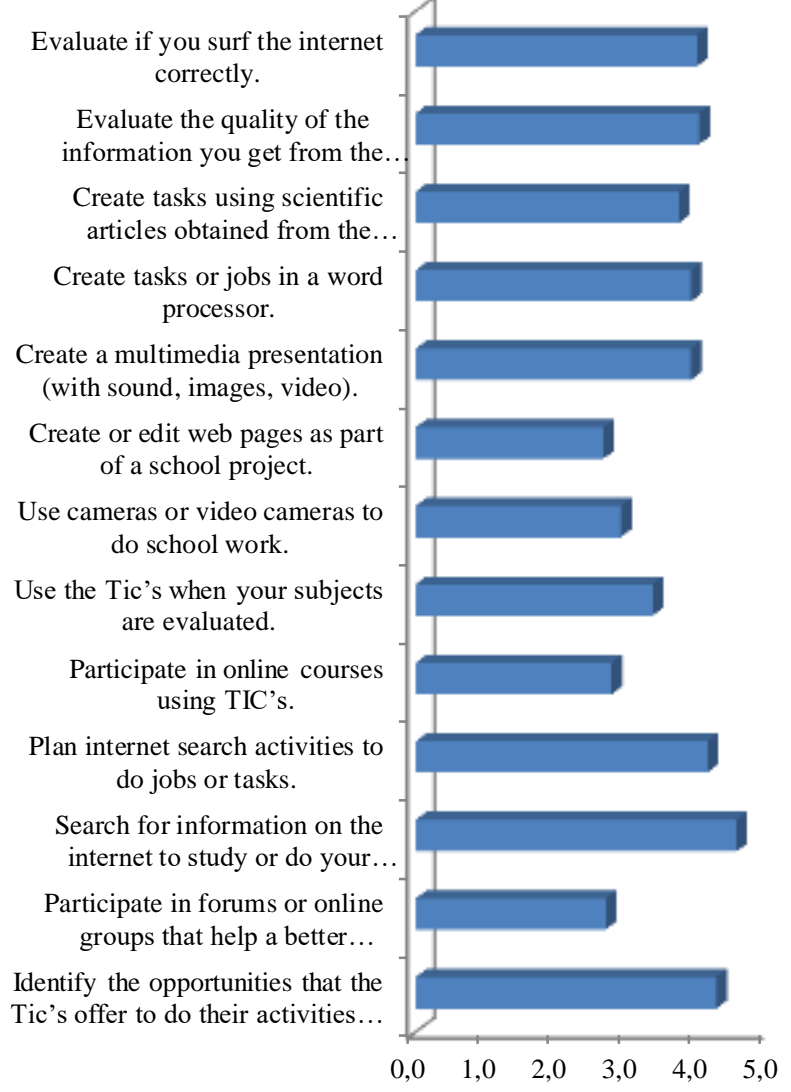

Graphic 5 Student Learning Competencies Source: Made with field information, 2018

As the students of the bachelor's degree in administration communicate at the beginning is what they tried to discover, on the one hand they use correctly at least one email between them and their teachers. On the other hand, they use well the power point and some word processor, (graph 6). But they don't participate so much in videoconferences. Neglecting how novel the use of this way of interacting and communicating can be.

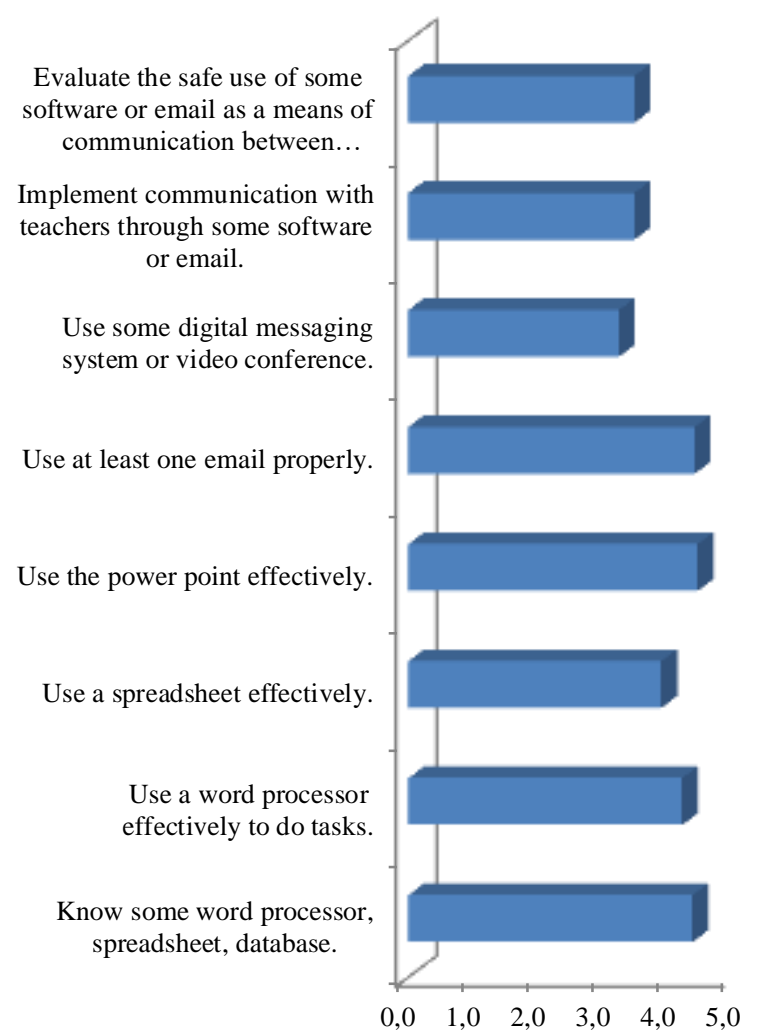

Graphic 6 Student communication skills Source: Made with field information, 2018

\section{Acknowledgment}

This work shows some of the results described below: Use and application of ICT in higher education institutions in the Mayan area of the Camino Real in the State of Campeche. Which was funded by the National Technological Institute of Mexico and the Government of the State of Campeche through the 2018-2 call to support scientific and technological research in the educational programs of federal, decentralized and institute technological institutes and centers. For the support provided, both institutions are deeply thanked.

\section{Conclusions}

One of the most entrenched devices among students is the cell phone. This is an opportunity to work more with them for that device. The Laptop is the machine that students use most to do their jobs and tasks, this is favored with the public policies that have taken place in the area. On the other hand, it allows to promote more actions in the matter and to channel more opportunities for access to ICTs if they bring the programs to young students. 
The place where students access the internet is at school. Therefore, an ICT policy in the institution favors that young students increase their potential in the use of these technologies. This is of vital importance to take into account since as we see the school represents for many young people the only door to access to the internet and the world of ICT.

As we mentioned the time of use of any of the devices such as Laptop, cell phone, computer, etc., a day was 5.6 hours on average for all respondents. The time on the internet to do their activities was 4.1 hours on average. In this sense, the time taken to do their homework was 4.5 hours on average per day. The time in a social network was 2.6 hours. Here you have what students do per day and we see how time is used both inside and outside the technology. However, this generates a greater distraction in the students since there is no direct impact with their school performance.

\section{References}

Aris N. y Orcos L. (2015). ICTs and School Education. International Journal of Interactive Multimedia and Artificial Intelligence, Vol. 3, No4, 13-18. DOI: 10.9781/ijimai.2015.342

Arras Vota, Ana María de Guadalupe, Torres Gastelú, Carlos Arturo, García-Valcárcel Muñoz-Repiso, Ana, (2011) Competencias en Tecnologías de Información y Comunicación (TIC) de los estudiantes universitarios. Revista Latina de Comunicación Social (66-2011), 126. Recuperado el 12 de Mayo de 2019 de: http://www.redalyc.org/articulo.oa?id=8192134 0018> ISSN.

Asociación Nacional de Universidades e Instituciones de Educación Superior [ANUIES] (2016). Estado actual de las tecnologías de la información y las comunicaciones en las instituciones de educación superior en México. Estudio ejecutivo. México.

Coronado E. y Cantú M. (2014). Diagnóstico universitario sobre el uso de la TIC en el proceso de enseñanza-aprendizaje bajo la modalidad educativa presencial en Santo Domingo. EDUTEC. Revista Electrónica de Tecnología Educativa. Núm. 50.

Fernández y Delavaut (2006).Educación y tecnología, un binomio excepcional. Ed. Martín Delavaut. España.
García M., Reyes J., Godínez G. (2017) Las Tic en la educación superior, innovaciones y retos. Revista Iberoamericana de las Ciencias Sociales y humanísticas. Vol. 6, Núm. 12.

Hernández, L.; Acevedo A., Martínez C., Cruz, C., (2014). El uso de las TIC en el aula: un análisis en términos de efectividad y eficacia. Congreso Iberoamericano de ciencia, tecnología, innovación y educación. Buenos Aires, Argentina. Disponible en: file://C:/Users/Usuario/Downloads/523\%20(1). pdf

Jimmy K.N. Macharia \& Theunis G. Pelser (2014) Key factors that influence the diffusion and infusion of information and communication technologies in Kenyan higher education, Studies in Higher Education, 39:4, 695-709, DOI: $10.1080 / 03075079.2012 .729033$

La Comisión Económica para América Latina [CEPAL] (2016). "Estado de la banda ancha en América Latina y el Caribe 2016." Recuperado el 11 de Mayo del 2019 de: https://www.cepal.org/es/publicaciones/40528estado-la-banda-ancha-america-latina-caribe2016

La Organización de las Naciones Unidas para la Educación, la Ciencia y la Cultura [UNESCO] (2019). "Las competencias digitales son esenciales para el empleo y la inclusión social". Recuperado el 15 marzo 2018 de: https://es.unesco.org/news/competenciasdigitales-son-esenciales-empleo-y-inclusionsocial

Pontificia Universidad Javeriana de Cali y UNESCO, (2016). Competencias y estándares TIC desde la dimensión pedagógica: Una perspectiva desde los niveles de apropiación de las TIC en la práctica educativa docente. Ed. Pontificia Universidad Javeriana - Cali. Colombia

Sangrá A. y González M. (Coord.) (2004). La transformación de las universidades a través de las TIC: discursos y prácticas. Ed. UOC. Barcelona, España.

Sosa M. y Valverde J. (2015). El equipo directivo "e-competente" y su liderazgo en el proceso de integración de las tic's en los centros educativos. Revista Iberoamericana de Evaluación Educativa, 8(2), 77-103.

BACAB-SANCHEZ, José R., AVILA-ORTEGA, Jorge I., SANTOSVALENCIA, Raúl A. and MAY-OSIO, Eduardo. Use and application of information and communication technologies in the students of the degree in administration of the Tecnologico de Calkini. Journal of Computational Svstems and ICTs. 2019. 
Vidal M. (2006). Investigación de las TIC en la educación. Revista Latinoamericana de Tecnología Educativa, 5 (2), 539-552. Recuperado el 13 de Mayo del 2018 de: http://www.unex.es/ didáctica/RELATEC/sumario_5_2.htm 